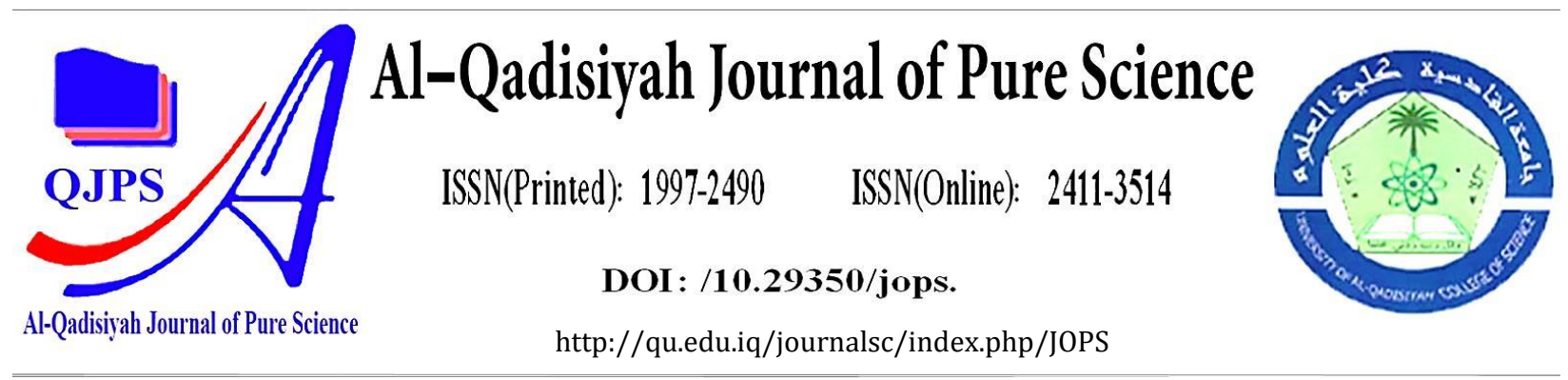

\title{
Study the anti - inflammatory effect of Stevia rebaudiana sweetness in vitro
}

\section{Authors Names \\ a. Meison Abdulbary \\ b. Suaad Lateef Ibrahim \\ c. Albasheer Ammar \\ d. Muhanad Mohammed \\ e. Wafaa Yousif \\ Article History \\ Received on:26/6/2021 \\ Revised on: 20/7/2021 \\ Accepted on: 25/7/2021 \\ Keywords: \\ Stevia rebaudiana, sweetness , anti - inflammatory \\ DOI: https://doi.org/10.29350/ \\ jops.2021.26. 4.1404}

\begin{abstract}
Because of the high rates of diabetes, overweight disorders and fatness, the need and interest in finding alternatives to sugar has increased, especially in the industrial sector in parallel with reducing the daily intake of sugar by human. This research was developed to identify the active ingredients which include in the plant aqueous extract of Stevia rebaudiana. Chemical examination showed the glycosides and phenolic compounds presence of in the Stevia rebaudiana plant. The effect of Stevia rebaudiana leaves products aqueous extract as anti-inflammation measured in vitro with two procedures, The repression of protein denaturation and hemolysis stimulated by heating and results showed Stevia rebaudiana efficiency with compared to typical medicine (Aspirin) and negative control groups.
\end{abstract}

\section{Introduction}

Because of the high rates of diabetes, overweight disorders and fatness, the need and interest in finding alternatives to sugar has increased, especially in the industrial sector in parallel with reducing the daily intake of sugar by human [20]. Thus, attention was drawn to the natural sweeteners produced from plants and herbs as Stevia rebaudiana Bert. Plant. that, stevia leaves have an important non calories secondary metabolites in glycosides form which are used in abundance in food industry as one kgm of stevia products is about 200 times sweeter than sucrose products without calories [27,17].

Stevia rebaudiana Bert. is a branched bushy shrub, the plants first grew in South America, especially in Paraguay, and is now grown in North American countries such as Canada, as well as parts of Asia

a,c,d,e Faculty of Pharmacy /University of Kufa, Republic of Iraq. E-Mail: maysoona.abdullah@uokufa.edu.iq

b Faculty of Pharmacy /University of Kufa, Republic of Iraq. E-Mail: asadsuaad@yahoo.com 
and Europe [13]. Its leaves contain many phytochemicals such as flavonoids, hydrodynamic acid and sugar-free amino acids [15].

In addition to sweeting properties, leaves of $S$. rebaudiana has therapeutic properties like anti carcinogenic, antimicrobial, antiviral , anti-hypertension , antihyperglyceamia , antitumor, antioxidant , antidiarrheal, diuretic, hepatoprotective, immunomodulatory [7,28,10,4]. Also it plays an important role as a harmless and safe alternative source to regular sugar in human daily use and does not pose any danger to health [20].

The defense response of living cells to damage such as burns or wounds and contamination by foreign bodies for restricting and localizing irritation, infection and causative agents called inflammation [24]. The signs of these response involve redness, heat, pain, swelling as well as lack of function [13]. In the living body, Inflammation begin during few minutes to several hours from harm start with acute manner and inflamed tissues may healed near few days and when it persist for more period will turn into chronic which may continue to along time near several months [4].

Many drugs used to treat inflammation as diclofenac and mefenamic acid and many other treatments [8]. Because of the wickedness harm and toxicity of some synthetic treatments, the use of nonsynthetic treatments which obtained from medicinal plants are becoming popular [23] that the plants such yarrow, bastard myrobalan, turmeric and myrrh are used to deal the inflammation in numerous cases [2]. Stevia rebaudiana plant product anti-inflammatory activity had been studied in vitro in this study.

\section{Materials and methods:}

\subsection{Stevia rebaudiana Bert extract:}

The sweeteners natural plant products were collected from Al - Najaf city markets, add 25 gm of plant sugar powder to $250 \mathrm{ml}$ of distilled water after mixed with small amounts of DMSO, mixed, filtered and reduction of size and dried, finally stored in refrigerator till it used, also the investigation of active constituents presence tests was done [7].

\section{2: Anti-inflammatory action study:}

\section{A. The inhibition of protein denaturation:}

In triplicate work, $1 \mathrm{ml}$ of prepared extract with concentrations (1000 and $2000 \mu \mathrm{g} / \mathrm{ml}$ ) was added to $1 \mathrm{ml}$ albumin protein solution which is $1 \%$ aqueous solution of bovine serum. the mixtures located in incubation $(20 \mathrm{~min})$ first at $37^{\circ} \mathrm{C}$, and second at $51^{\circ} \mathrm{C}(20 \mathrm{~min})$, then cool and measured the absorbance by spectrophotometer $(660 \mathrm{~nm})$ [1]. Inhibition was valued as:

Inhibition rate $=($ Cabsorbance - Sabsorbance $) \times 100 /$ Cabsorbance .

( C:control and S:sample ) 


\section{B. ( RBCs) suspension:}

The blood samples had been took from a robust and healthy animated donors which about 2 weeks before investigational work have not taken any inflammation treatments. About $10 \mathrm{ml}$ from above fully unblemished blood samples are for 10 minutes centrifuged at $3000 \mathrm{round} / \mathrm{min}$, then washed( diluted ) with similar volume of normal saline for 3 times [21].

\section{Stimulation of hemolysis by heating:}

The plant extract which concentrations (1000 and $2000 \mu \mathrm{g} / \mathrm{ml})$ were centrifuged by adding ( $1 \mathrm{ml})$ of extract in tubes and $(1 \mathrm{ml})$ of $\mathrm{RBCs}$ suspension $(10 \%$ solution). Aspirin $(100 \mu \mathrm{g} / \mathrm{ml})$ represent a standard +ve control and saline's only solution represent the -ve control also centrifuged with $10 \%$ RBCs suspension as in plant extract, all tubes ( to keep them warmly) were putting in water bath at 56 ${ }^{\circ} \mathrm{C}$ about (30 $\mathrm{min}$ ), and by tap water then were cooled. Lastly, the solutions with RBCs were centrifuged at 2500 round / minute for 5 min then absorbance of upper parts was measured at $560 \mathrm{~nm}$ [10]. Inhibition was valued as below:

Inhibition rate $=(\mathrm{C}$ absorbance $-\mathrm{S}$ absorbance $) \mathrm{X} 100 / \mathrm{C}$ absorbance.

\section{Results and discussion:}

The chemical investigation for phytochemicals may present in aqueous extracts of Stevia rebaudiana by reagents was showing the occurrence of phenolic composition and glycosides which as showed in prior researches [17]. Elements of lysosomes membranes are similar to that which found in human red blood corpuscle (HRBC) membrane [22], therefore, the human red blood corpuscle (HRBC) were thoughtfully preferred to studying the actions of many substances especially the toxics because of their availability and simplicity of getting them [18].The membrane stability is highly importance in lysosomes membranes since during inflammation, the lysosomal enzymes will be free activate that lead to cell damage breakdown by rupture of the cells membranes resulting lack or absence of cations from the membranes [5] in addition protein configuration will be crashed or broken by denaturation [11]. Aspirin which is consider as non-steroidal anti-inflammation drugs plays a role in the lysosomal membrane stability beside the lysosomal enzymes action inhibition [25]. The probable effect of plant extract is resulting in membrane stability and avoiding protein denaturation which was reflected in vitro with stimulation of hemolysis by heating and the inhibition of protein denaturation that explained by figures (1) \& (2).

Stevia rebaudiana plant indicated significant action when compared to Aspirin when studied RBCs hemolysis induced by heat at different effective concentrations. Also Stevia rebaudiana played a role in avoiding denaturation of protein with studied concentrations. The effects indicated that plants include active constituents aid in preserving lysis and maintains the RBCs membranes efficiently and may be inhibit the lysosome enzymes liberation and develop the membrane stability since of glycosides presence will enhance the reaction of attachments to bivalent cations as $\mathrm{Ca}^{+2} \mathrm{and} \mathrm{Mg}^{+2}$ [15] 
beside that, anti-inflammatory action which avoid denaturation of protein perhaps because alkaloid, polyphenolic compounds and phenolic acid may present in extract [3].

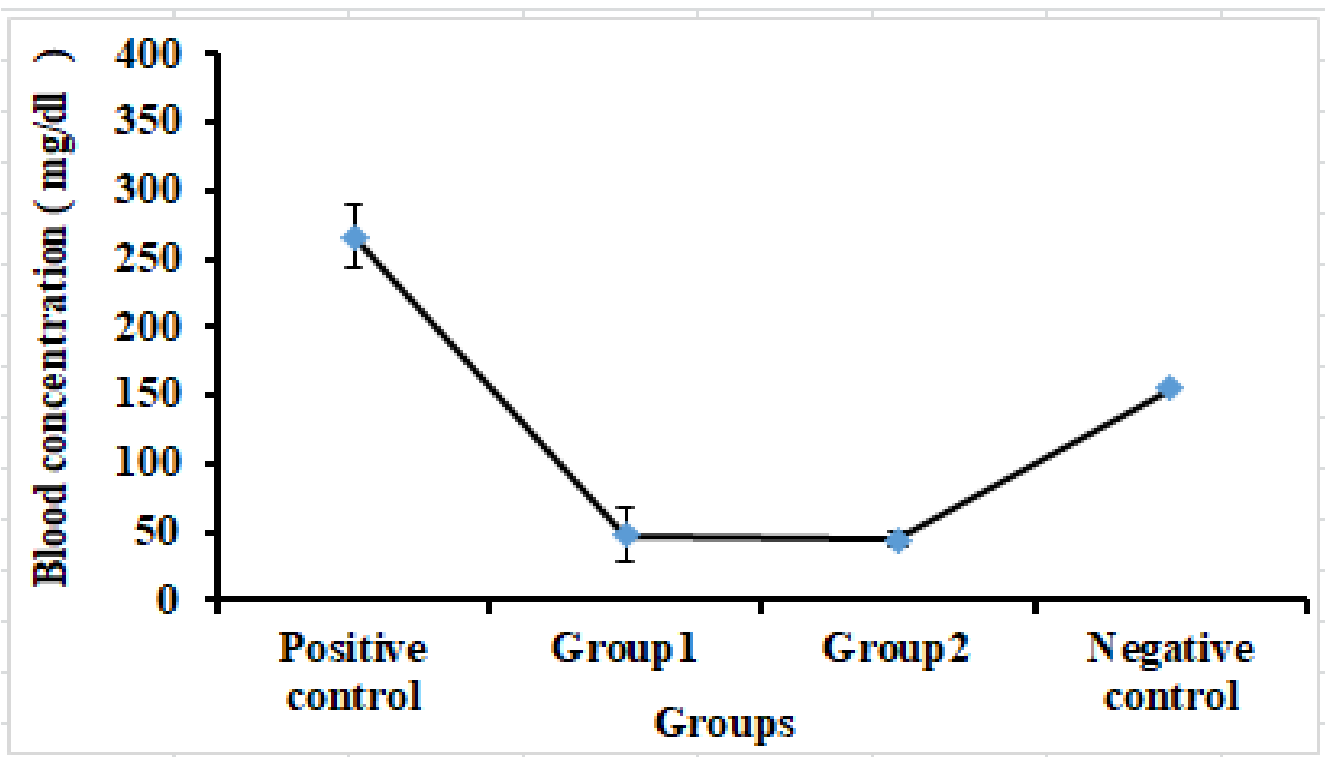

Figure(1) : Stimulation of hemolysis by heating on RBCs with Stevia rebaudiana. (group1: 1000 $\mu \mathrm{g} / \mathrm{ml}$, group2: $2000 \mu \mathrm{g} / \mathrm{ml}$ plant extract).

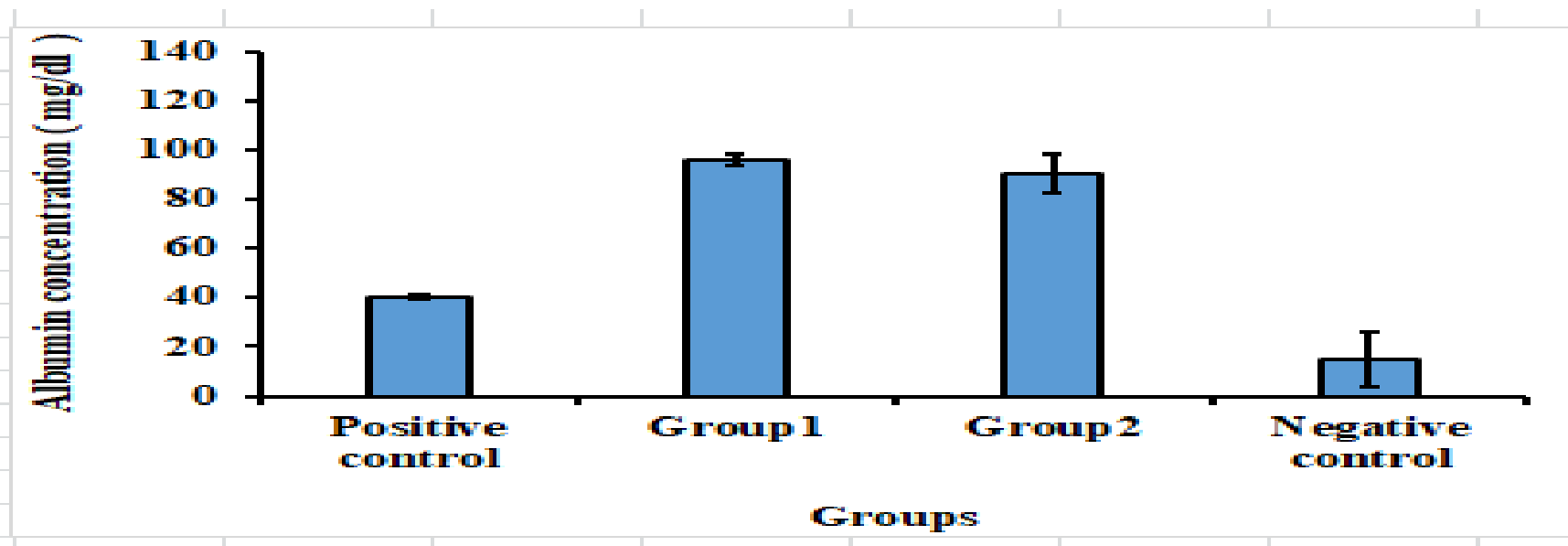

Figure ( 2 ) : The inhibition of protein denaturation activity of Stevia rebaudiana extract results. ((group1: $1000 \mu \mathrm{g} / \mathrm{ml}$, group2: $2000 \mu \mathrm{g} / \mathrm{ml}$ plant extract).).

\section{Acknowledgements:}

We are very grateful for the continuous support and encouragement made by the members of Department of Pharmacognosy and Medicinal Plant / Faculty of Pharmacy /University of Kufa. 


\section{References :}

[1]Agnihotri,S. ; Wakode, S. and Agnihotri, A. ( 2010). An overview on anti-inflammatory properties and chemo-profiles of plants used in traditional medicine. IJNPR.1(2): 150-167.

[2] Barnig, C. and Levy , B.D. ( 2015 ). Innate immunity is a key factor for the resolution of inflammation in asthma. European Respiratory Review. 24: 141-153.

[3] Chandra, S. ; Chatterjee, P. ; Dey, P. and Bhattacharya , S. ( 2012 ). Evaluation of in vitro antiinflammatory activity of coffee against the denaturation of protein. Asian Pacific Journal of Tropical Biomedicine. S178-S180.

[4] Chatsudthipong V. and Muanprasat C.(2009). Stevioside and related compounds: therapeutic benefits beyond sweetness. Pharmacology \& Therapeutics. 121:41-54.

[5] Chippada, S.C. ; Volluri, S.S. ; Bammidi , S.R. and Vangalapati , M. ( 2011 ). In vitro antiinflammatory activity of methanolic extract of Centella asiatica by HRBC membrane stabilisation. Rasayan J. Chem.. 4(2): 457-460.

[6] Gardana C, Scaglianti M, Simonetti P. (2010). Evaluation of steviol and its glycosides in Stevia rebaudiana leaves and commercial sweetener by ultra-high performance liquid chromatographymass spectroscopy. J Chromatogr A. 1217:1463-70.

[7] Harborne,J.B. (1984). Phytochemical methods ; A guide to modern techniques of plant analysis , 2nd ed. Chapman and Hall , London. pp 307.

[8] Henson , P.M. ( 2005 ).Dampening inflammation. Nat Immunol. 6: 1179-81.

[9] Kedik SA, Yartsev EI, Stanishevskaya IE. (2009). Antiviral activity of dried extract of Stevia. Pharm Chem J. 43:198-99.

[10] Kumar, S. ; Bajwa1, B.S. ; Kuldeep ,S. and Kalia ,A.N. ( 2013 ). Anti-Inflammatory Activity of Herbal Plants: A Review. IJAPBC. 2(2): 272 - 281.

[11] Leelaprakash , G. and Dass , S.M. ( 2011 ). In vitro anti-inflammatory activity of methanol extract of Enicostemma axillare. Int. J. Drug Dev. \& Res. 3(3): 189-196.

[12] Lemus-Mondaca, R., Vega-Galvez, A., Zura-Bravo, L., Ah-Hen, K. (2012). Stevia rebaudiana Bertoni, source of a high-potency natural sweetener: a comprehensive review on the biochemical, nutritional and functional aspects. Food Chem. 132: 1121-1132.

[13] Mohan K and Robert J. ( 2009). Hepato protective effects of Stevia rebaudiana Bertoni leaf extract in CCl4-induced liver injury in albino rats. Med Aromat Plant Sci Biotechnol.3:59-61.

[14] Muanda, F.N., Soulimani, R., Diop, B., Dicko, A. (2011). Study on chemical composition and biological activities of essential oil and extracts from Stevia rebaudiana Bertoni leaves. LWT-Food Sci. Technol. 44: 1865-1872.

[15] Oyedapo , O.O. ; Akinpelu, B.A. ; Akinwunmi , K.F. ; Adeyinka , M.O. and Sipeolu , F.O. ( 2010 ). Red blood cell membrane stabilizing potentials of extracts of Lantana camara and its fractions. International Journal of Plant Physiology and Biochemistry. 2(4): 46-51.

[16] Ranjan,R; Jaiswal, J. and Jena, J. (2011). Stevia as a natural sweetener. International Journal Of Research In Pharmacy And Chemistry IJRPC. 1(4):1199-1202.

[17] Sakat , S.; Juvekar , A.R. and Gambhire , M.N. ( 2010). In vitro antioxidant and antiinflammatory activity of methanol extract of Oxalis corniculata Linn. International Journal of Pharma and Pharmacological Sciences. 2(1):146-155. 
[18] Salih, S.M. ; Alobaidi , K.H. and Alobaidi , Z.F.( 2015 ). Cytotoxic Effect of Rosmarinus officinalis L. Leaf Extracts on Tumor Cell Line. Journal of Al-Nahrain University.18 (4): 98-102. Science.

[19] Samuel,P.; Ayoob, K.T. ; Magnuson,B.A. ; Wölwer-Rieck,U.; Jeppesen,P.B.; Rogers, P.J. ; Rowland, I and Mathews, R. (2018). Stevia Leaf to Stevia Sweetener: Exploring Its Science, Benefits, and Future Potential. The Journal of Nutrition, 148(7): 1186S-1205S.

[20] Savita S.M., Sheela K., Sunanda S., Shankar A.G., and Ramakrishna P.(2004). Stevia rebaudiana - a functional component for food industry. Journal of Human Ecology. 15(4): 261264.

[21] Shaikh ,R.U. ; Pund, M. M. and Gacche, R.N. ( 2016 ). Evaluation of anti-inflammatory activity of selected medicinal plants used in Indian traditional medication system in vitro as well as in vivo. Journal of Traditional and Complementary Medicine. 6(4): 355-361

[22] Shinde, U.A.; Kulkarni, K.R.; Phadke, A.S.; Nair , A.M.; Dikshit , V. J.; Mungantiwar and Saraf, M.N.( 1999 ). Mast cell stabilizing and lipoxygenase inhibitory activity of Cedrus deodara (Roxb.) Loud. Wood Oil. Indian J Exp Biol. 37(3): 258-261.

[23] Stankov , S.V. ( 2012 ). Definition of Inflammation, Causes of Inflammation and Possible Anti-inflammatory Strategies. The Open Inflammation Journal. 5: 1-9.

[24] Takahashi K, Matsuda M, Ohashi K, Taniguchi K, Nakagomi O, Abe Y, et al.(2001). Analysis of anti-rotavirus activity of extract from Stevia rebaudiana. Antiviral Res. 49:15-24.

[25] Vadivu ,R. and Lakshmi K.S. (2008). In vitro and in vivo anti-inflammatory activity of leaves of Symplocos cochinchinensis (Lour) Moore ssp Laurina. Bangladesh J Pharmacol. 3: 121-124.

[26] Wölwer-Rieck, U. ( 2012). The leaves of Stevia rebaudiana Bertoni, their constituents and the analyses thereof: a review. J Agric Food Chem. 60:886-895.

[27] Zaidan U. H., Hamid, S. N. M., Yusof, M. F. M., Ahmad, S, Gani, S. S. A., Shamsi, S. (2018). Chemical evaluation and antioxidant properties of extracts and essential oil from Stevia rebaudiana. Malaysia Applied Biology Journal. 47(2):15-23. 